\title{
Well-preserved fenestrate bryozoans in Mississippian building stones, Utrecht, The Netherlands
}

\author{
Stephen K. Donovan ${ }^{1,2} \cdot$ Patrick N. Wyse Jackson ${ }^{3}$
}

Received: 11 July 2017 / Accepted: 25 October 2017/Published online: 15 November 2017

(C) Akademie der Naturwissenschaften Schweiz (SCNAT) 2017

\begin{abstract}
Unusually well-preserved fenestrate bryozoans have been identified in Mississippian (Lower Carboniferous) building stones in Utrecht, the Netherlands. Specimens in adjacent properties presumably came from the same horizon, presumably from Belgium. Although scant internal morphological detail can be discerned, the general arrangement of the meshwork, together with the disposition of autozooecia, show affinities with Rectifenestella Morozova, which has straight-sided fenestrules into which lateral autozooecial apertures do not extend. This may be the first detailed record of bryozoans from the Mississippian building stones of the Netherlands.
\end{abstract}

Keywords Urban geology · Lower Carboniferous ·

Taphonomy $\cdot$ Konservat-Lagerstätten · Belgium

\section{Introduction}

Over most of the Netherlands, the landscape lacks natural elevations in topography or rocky outcrops, the geology being comprised of, dominantly, a thick succession of flat-

Handling editor: D. Marty.

Stephen K. Donovan

Steve.Donovan@naturalis.nl

Patrick N. Wyse Jackson

wysjcknp@tcd.ie

1 Taxonomy and Systematics Group, Naturalis Biodiversity Center, 9517, 2300 RA Leiden, The Netherlands

2 Department of Earth Sciences, University of New Brunswick, Fredericton, NB E3B 5A3, Canada

3 Department of Geology, Trinity College, Dublin, Ireland lying, unlithified Quaternary sediments (Meijer 1985). In such a setting, building stones take on an additional significance for the geologist. That is, where there are no rocks in situ, specimens transported and accumulated by mankind provide both aesthetic pleasure, and, potentially, opportunities for fieldwork and research (e.g., Donovan 2015). Common building stones in Dutch cities include various grey Upper Palaeozoic limestones, mostly Mississippian (Lower Carboniferous), and which were imported from Belgium and elsewhere. Palaeontological field guides to these limestones, such as Reumer (2016) and Van Roekel (2007), illustrate and document the prominent Mississippian taxa including tabulate and rugose corals, crinoids, brachiopods and molluscs (Donovan and Madern 2016; Donovan et al. 2017).

Bryozoans are present in these limestones, but are commonly poorly preserved as small $(<10 \mathrm{~mm})$, broken fragments that have previously received little attention. It is, therefore, considered significant to record the specimens described below; these are most unusual, occurring in the facing stones of two adjacent buildings, and being both large and remarkably complete. This may be the first detailed record of bryozoans from the Mississippian building stones of the Netherlands.

\section{Locality and horizon}

The two specimens discussed herein (Figs. 1, 2) are exposed in adjacent properties on the Maliebaan, Utrecht, the Netherlands. This street can be attained by the bus number 3 from Utrecht Centraal railway station to the stop closest to Het Spoorweg Museum (= National Railway Museum). Maliebaan is the main road that leads from the bus stop to the museum. 

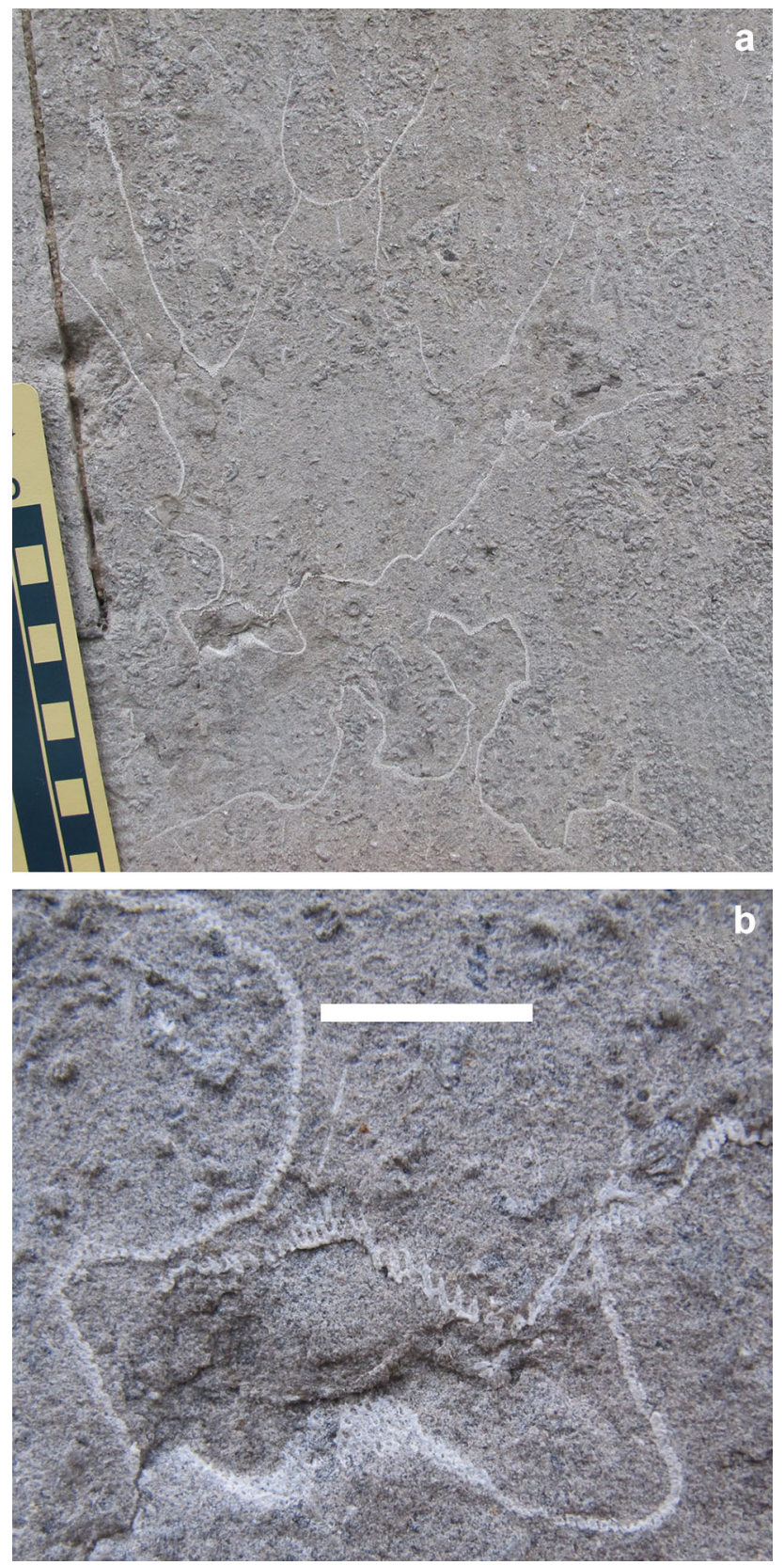

Fig. 1 Maliebaan 15, Utrecht, fenestrate bryozoan. a Complete specimen showing complex branching pattern exposed in two dimensions. Scale in $\mathrm{cm}$. b Detail of part of structure to demonstrate fenestration. Scale bar represents $10 \mathrm{~mm}$

Maliebaan 15 is currently a branch of the Rabobank. The fenestrate colony (Fig. 1) is situated about $0.8 \mathrm{~m}$ above the pavement, to the right of a barred cellar window; this is the second window to the left of the tall gates. This large colony is about $170 \mathrm{~mm}$ wide by $240 \mathrm{~mm}$ high.

Maliebaan 13 exposes a further, smaller fenestrate colony (Fig. 2) to the left of the door, below head height and about $120 \mathrm{~mm}$ in maximum dimension. Associated faunal elements apparent in both buildings include solitary rugose corals and, rarely, the tabulate colony Michelinia (compare
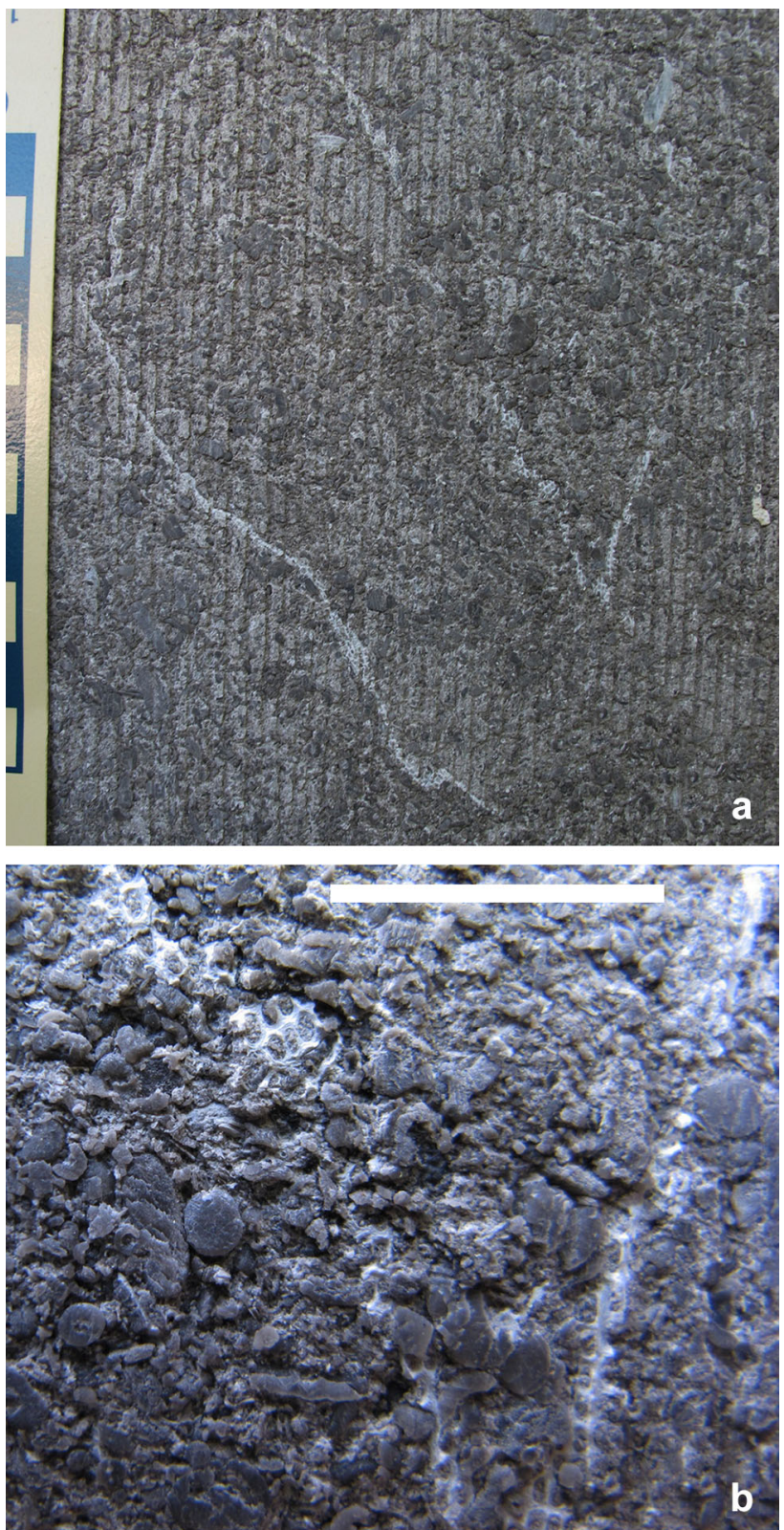

Fig. 2 Maliebaan 13, Utrecht, fenestrate bryozoan. a Complete specimen showing simple branching pattern exposed in two dimensions. Scale in $\mathrm{cm}$. b Detail of part of structure to demonstrate fenestration. Scale bar represents $10 \mathrm{~mm}$

with Van Ruiten and Donovan 2018), indeterminate brachiopods, low-coiled molluscs apparently lacking septa [gastropods(?) or, more likely, imperfectly preserved goniatites; Reumer 2016, Figs. 50-53, contra Donovan 2016] and crinoid debris.

In common with similar facing stones throughout the Netherlands, the lithology and fauna are most indicative of the Mississippian (Lower Carboniferous). The probable country of origin is Belgium (Van Roekel 2007, p. 2; Van Ruiten and Donovan 2018). 


\section{Description}

Exposed in the building stone are colonies of stenolaemate bryozoans belonging to the Order Fenestrata, which are characteristic of the Family Fenestellidae (Bassler 1953; McKinney and Wyse Jackson 2015). These possess a reticulated zoarium comprising straight to sinuous branches joined by short lateral dissepiments, and form broad planar or undulating fan-shaped, or cone-shaped expansions. Colonies originate from a small holdfast normally attached to a hard substrate, and branches diverge and grow distally up into the water column. Branches of the members of the Family Fenestellidae carry two rows of autozooecia (the feeding zooids of the colony) that open out onto obverse surface, and utilise a lophophore to capture food. The reverse surface is barren and often longitudinally striated. The arrangement of branches and dissepiments delineate fenestrules (openings) in the meshwork and in this case they are rounded-rectangular in shape surrounded by approximately six to eight autozooecial apertures (Fig. 2a).

Prior to the 1970s, generic characterisation of fenestrate bryozoans was largely determined by the external morphology and meshwork characteristics, but since then it has been demonstrated that the additional recognition of internal features is essential to distinguish taxa (Morozova 1974). Two taxa with broadly identical meshwork parameters may belong to quite separate genera. In the case of the fenestellids described here, scant internal morphological detail can be discerned, but the general arrangement of the meshwork, together with the disposition of autozooecia show affinities with Rectifenestella Morozova, 1974, which has straight-sided fenestrules into which lateral autozooecial apertures do not extend. Ernst et al. (2017) reported $R$. polyporata (Phillips 1836) from the Molignée Formation (lower Viséan) of southern Belgium, although this species generally has more elongate fenestrules than the material in Utrecht.

\section{Discussion}

The preservation of these fenestellid bryozoan colonies is exceptionally fine and the colony illustrated in Fig. 1 is particularly intact. The largest fenestellid colonies reported are those from the Mississippian of North America that reached a maximum of $620 \mathrm{~mm}$ wide by $44 \mathrm{~mm}$ high in the case of Hemitrypa perstriata Ulrich (1890) (Snyder 1991).

The most notable feature of these specimens is the complete, apparently three-dimensional preservation (Figs. 1, 2). Because the colonies are only apparent in two dimensions, it is impossible to determine how much post- mortem collapse has occurred, if any. Assuming the facing stones to be cut parallel to bedding, as has been commonly observed (S.K.D. unpublished observations), then both colonies were lying on the seafloor, but early burial and/or diagenesis probably maintained them in three dimensions. In life, these colonies would have grown erect into the water column and, subsequent to death, specimens commonly became highly fragmented due to bioerosion, current action or compactional damage (Key et al. 2016). In the Mississippian Waulsortian facies of Belgium, fenestellid bryozoans often formed wide expansions similar in dimensions to those observed in the buildings in Utrecht (Wyse Jackson 2006). These were capable of baffling sediment (McKinney et al. 1987; Suárez Andrés and Wyse Jackson 2015), and these subsequently contributed to mudmound stability when they toppled over and trapped sediment beneath (Wyse Jackson 2006).

Hitherto, S.K.D. has only seen fenestrates in such building stones in the Netherlands as rare and invariably small fragments. The occurrence of these specimens in adjacent buildings suggests that they may have been cut from the same sedimentary bed and, indeed, could even be contrasting sections through the same colony.

To put this in perspective, S.K.D. has been searching approximately coeval building stones in the Netherlands for well-preserved echinoids, and crinoid cups and crowns, for over 10 years, but to no avail; the long pluricolumnal described in Donovan et al. (2017) is the most complete specimen found to date. The fenestrate bryozoan specimens considered herein are both large and exceptionally well preserved, and could represent a bryozoan KonservatLagerstätten, albeit of unknown provenance. However, the presence of fenestellid bryozoans in this dimension stone strongly point to a Belgian origin, and this report is another example of the use of these colonial invertebrates as provenance indicators for Mississippian building stones (see Key and Wyse Jackson (2014) for further examples from Belgium and the US).

Acknowledgements We thank our reviewers, Professor Marcus M. Key (Dickinson College Carlisle, PA) and one anonymous reviewer, and our editor, Dr Daniel Marty, for their constructive comments.

\section{References}

Bassler, R. S. (1953). Bryozoa. In R. C. Moore (Ed.), Treatise on invertebrate paleontology, Part G. New York and Lawrence: Geological Society of America and University of Kansas.

Donovan, S. K. (2015). Urban geology: boulders and the Dutch. Deposits, 42, 8-9.

Donovan, S. K. (2016). A mollusc-coral interaction in a paving slab, Leiden, the Netherlands. Bulletin of the Mizunami Fossil Museum, 42, 45-46. 
Donovan, S. K., Jagt, J. W. M., \& Jagt-Yazykova, E. A. (2017). A well-preserved crinoid stem in a building stone (Lower Carboniferous, Mississippian) at Maastricht, the Netherlands. Bulletin of the Mizunami Fossil Museum, 43, 23-25.

Donovan, S. K., \& Madern, P. A. (2016). Rostroconchs in Leiden. Swiss Journal of Palaeontology, 135, 349-352.

Ernst, A., Tolokonnikova, Z., Poty, E., \& Mottequin, B. (2017). A bryozoan fauna from the Mississippian (Tournaisian and Viséan) of Belgium. Geobios, 50, 105-121.

Key, M. M., Jr., \& Wyse Jackson, P. N. (2014). Use of fossil bryozoans as provenance indicators for dimension stones. Studi Trentini di Scienze Naturali, 94, 131-138.

Key, M. M., Wyse Jackson, P. H., \& Felton, S. H. (2016). Intracolony variation in colony morphology in reassembled fossil ramose stenolaemate bryozoans from the Upper Ordovician (Katian) of the Cincinnati Arch region, USA. Journal of Paleontology, 90, 400-412.

McKinney, F. K., McKinney, M. J., \& Listokin, M. R. A. (1987). Erect bryozoans are more than baffling: enhanced sedimentation rate by a living unilaminate bryozoan and possible implications for fenestrate bryozoan mudmounds. Palaios, 2, 41-47.

McKinney, F. K., \& Wyse Jackson, P. H. (2015). Part G, Revised, Volume 2, Chapter 8A: Order Fenestrata: Morphology and growth. Treatise Online, 66, 1-91.

Meijer, H. (1985). Compact Geography of the Netherlands. Fifth impression (pp. 43). Utrecht: Ministry of Foreign Affairs, The Hague, and Documentation Centre for the Geography of the Netherlands (IDG).
Morozova, I. P. (1974). Revision of the bryozoan genus Fenestella. Paleontological Journal, 8, 167-180.

Phillips, J. (1836). Illustration of the geology of Yorkshire, or a description of the strata and organic remains, part 2. The Mountain Limestone districts. London: John Murray.

Reumer, J. (2016). Kijk waar je loopt! (p. 136). Historische Uitgeverij: Over stadspaleontologie.

Ruiten, D. M. van \& Donovan, S. K. (2018). Provenance, systematics and palaeoecology of Mississippian (Lower Carboniferous) corals (subclasses Rugosa, Tabulata) preserved in an urban environment, Leiden, the Netherlands. Bulletin of the Mizunami Fossil Museum.

Snyder, E. M. (1991). Revised taxonomic procedures and paleoecological applications for some North American Mississippian Fenestellidae and Polyporidae (Bryozoa). Palaeontographica Americana, 57, 1-275.

Suárez Andrés, J. L., \& Wyse Jackson, P. H. (2015). Feeding currents: a limiting factor for disparity of Palaeozoic fenestrate bryozoans. Palaeogeography, Palaeoclimatology, Palaeoecology, 433, 219-232.

Ulrich, E. O. (1890). Palaeozoic Bryozoa: 3. Report of the Geological Survey of Illinois, 8, 283-688.

Van Roekel, A. (2007). Discover fossils in downtown Amsterdam: ancient ocean life in Amsterdam's alleys. Amsterdam: De Vuurberg.

Wyse Jackson, P. N. (2006). Bryozoa from Waulsortian buildups and their lateral facies (Mississippian, Carboniferous) in Belgium and Ireland. Senckenberg, Courier Forschungsinstitut, 257, 149-160. 